\title{
Phospholipids reduce gastric cancer cell adhesion to extracellular matrix in vitro
}

\author{
Marc Jansen*1, Karl-Heinz Treutner ${ }^{1}$, Britta Schmitz ${ }^{1}$, Jens Otto ${ }^{1}$, \\ Petra Lynen Jansen ${ }^{2}$, S Neuss ${ }^{3}$ and Volker Schumpelick ${ }^{1}$
}

\begin{abstract}
Address: ${ }^{1}$ Department of Surgery, University Clinic, Pauwelsstr. 30, 52057 Aachen, Germany, ${ }^{2}$ Interdisciplinary Centre of Clinical Research (IZKF) Biomat; University Clinic, Pauwelsstr. 30, 52057 Aachen, Germany and 3Institute of Pathology, University Clinic, Pauwelsstr. 30, 52057 Aachen, Germany

Email: Marc Jansen* - mjansen@ukaachen.de; Karl-Heinz Treutner - prof-kht@arcor.de; Britta Schmitz - schmitz.britta@web.de; Jens Otto - jeotto@ukaachen.de; Petra Lynen Jansen - plynen@ukaachen.de; S Neuss - sabine.neuss@gmx.de;

Volker Schumpelick - vschumpelick@ukaachen.de

* Corresponding author
\end{abstract}

Published: 29 December 2004

BMC Gastroenterology 2004, 4:33 doi:10.1186/I47/-230X-4-33
Received: 01 July 2004

Accepted: 29 December 2004

This article is available from: http://www.biomedcentral.com/l47I-230X/4/33

(C) 2004 Jansen et al; licensee BioMed Central Ltd.

This is an Open Access article distributed under the terms of the Creative Commons Attribution License (http://creativecommons.org/licenses/by/2.0), which permits unrestricted use, distribution, and reproduction in any medium, provided the original work is properly cited.

\begin{abstract}
Background: Nidation of floating tumour cells initiates peritoneal carcinosis and limits prognosis of gastro-intestinal tumours. Adhesion of tumour cells to extracellular matrix components is a pivotal step in developing peritoneal dissemination of intraabdominal malignancies. Since phospholipids efficaciously prevented peritoneal adhesion formation in numerous animal studies we investigated their capacity to reduce adhesions of gastric cancer cells to extracellular matrix components (ECM).
\end{abstract}

Methods: Human gastric cancer cells (NUGC-4, Japanese Cancer Research Resources Bank, Tokyo, Japan) were used in this study. Microtiter plates were coated with collagen IV (coll), laminin (In) and fibronectin (fn). Non-specific protein binding of the coated wells was blocked by adding $1 \%$ $(\mathrm{w} / \mathrm{v}) \mathrm{BSA}\left(4^{\circ} \mathrm{C}, 12 \mathrm{~h}\right)$ and rinsing the wells with Hepes buffer. 50.000 tumour cells in $100 \mu \mathrm{l}$ medium were seeded into each well. Beside the controls, phospholipids were added in concentrations of $0.05,0.1,0.5,0.75$ and $\mathrm{I} .0 / 100 \mu \mathrm{l}$ medium. After an incubation interval of $30 \mathrm{~min}$, attached cells were fixed and stained with $0.1 \%(\mathrm{w} / \mathrm{v})$ crystal violet. The dye was resuspended with $50 \mu \mathrm{l}$ of $0.2 \%(\mathrm{v} / \mathrm{v})$ Triton X-100 per well and colour yields were then measured by an ELISA reader at $590 \mathrm{~nm}$. Optical density (OD) showed a linear relationship to the amount of cells and was corrected for dying of BSA/polystyrene without cells.

Results: The attachment of gastric cancer cells to collagen IV, laminin, and fibronectin could be significantly reduced up to $53 \%$ by phospholipid concentrations of $0.5 \mathrm{mg} / 100 \mu \mathrm{l}$ and higher.

Conclusion: These results, within the scope of additional experimental studies on mice and rats which showed a significant reduction of peritoneal carcinosis, demonstrated the capacity of phospholipids in controlling abdominal nidation of tumour cells to ECM components. Lipid emulsions may be a beneficial adjunct in surgery of gastrointestinal malignancies. 


\section{Background}

In the treatment of gastro-intestinal cancer the detection of free, isolated tumour cells in the peritoneal cavity serve as a prognostic marker for postoperative survival [1-4]. Since surgery frequently proofs insufficient for tumour control, numerous additional treatments have been evaluated. A pivotal step in developing peritoneal dissemination seems to be adhesion of tumour cells to mesothelial cells or extracellular matrix components [5-7]. Experimental studies suggest that peritoneal metastases tend to occur in areas of injured peritoneum [8]. Cell-matrix interactions are promoted by transmembrane receptors with integrins as a major family. Many attempts were made to inhibit tumour cell attachment by antibodies against adhesion molecules [9], dextran sulphate [10], or sodium hyaluronate [11] with different results concerning tumour adhesion.

Phospholipids, polar phosphoric acid di-esters, are natural constituents of the abdominal fluid. The substance is able to form a lubricant layer on the peritoneal surface [12]. Additionally, integrin function, particularly in control of cell motility is affected by exogenous addition of phospholipids (e.g. gangliosides) [13,14]. Intraperitoneal use of phospholipids (PL) led to a significant decrease of adhesion formation especially at sites of peritoneal injury $[15,16]$. The objective of the underlying in vitro study was focused on the influence of phospholipids on adhesion of gastric cancer cells to extracellular matrix components with broad reactivity to several integrins. Collagen IV (coll IV), and laminin (ln) are main components of the basement membrane and fibronectin (fn) plays an important role in wound healing $[17,18]$.

\section{Methods}

\section{Tumour cells}

The human gastric cancer cell line NUGC-4 was purchased from the Japanese Cancer Research Resources Bank (Tokyo, Japan). The cells were maintained in monolayers in tissue culture flasks $\left(75 \mathrm{~cm}^{2}\right.$, Falcon, Becton Dickinson-Gambil, Heidelberg, Germany) in RPMI 1640 medium (GIBCO, Karlsruhe, Germany), supplemented with $10 \%$ foetal bovine serum (GIBCO), penicillin and streptomycin (GIBCO). Cell cultures were incubated at $37^{\circ} \mathrm{C}$ in a humidified atmosphere of $5 \% \mathrm{CO}_{2}$ in air. Cells were passaged after treatment with $0.125 \%$ trypsin for 6 min. The cells were pelleted after centrifugation for 10 min at $200 \mathrm{~g}$, suspended in $20 \mathrm{ml}$ PBS, and pelleted. The cell pellet was resuspended in $30 \mathrm{ml}$ complete medium and seeded with a splitting ratio of 1:3. Only cells from three passages were used for the experiments.

\section{Extracellular matrix (ECM) components}

Flat-bottom polystyrene microtiter plates (Becton Dickinson, Heidelberg, Germany) were coated for adhesion experiments. The purified ECM components were dissolved in PBS with the following concentrations: coll IV 2,5 $\mathrm{gg} / \mathrm{ml}$ (Biomol, Hamburg, Germany), fn - $10 \mu \mathrm{g} / \mathrm{ml}$ (Boehringer, Mannheim, Germany), ln - $50 \mu \mathrm{g} / \mathrm{ml}$ (Boehringer, Mannheim, Germany). We found these concentrations to be optimal in foregoing dilution series. They were added to the wells and incubated at $4^{\circ} \mathrm{C}$ for 24 hours (coll IV, fn), or at $37^{\circ} \mathrm{C}$ for $45 \mathrm{~min}$ in a humidified atmosphere of $5 \% \mathrm{CO}_{2}$ in air (ln), respectively. Nonspecific protein binding of the coated wells was blocked by adding $1 \%(\mathrm{w} / \mathrm{v}) \mathrm{BSA}\left(4^{\circ} \mathrm{C}, 12 \mathrm{~h}\right)$ and rinsing the wells with Hepes buffer.

\section{Adhesion assay}

For adhesion experiments gastric cancer cells were detached with collagenase I ( $15 \mathrm{~min}, 37^{\circ} \mathrm{C}$, Worthington, Freehold, USA), washed once with RPMI 1640, centrifuged (200 g for $10 \mathrm{~min}$ ), resuspended in RPMI 1640, and preincubated for $30 \mathrm{~min}$ in a humidified atmosphere of $5 \% \mathrm{CO} 2$ in $\operatorname{air}\left(37^{\circ} \mathrm{C}\right)$. Fifty thousand tumour cells in 100 $\mu \mathrm{l}$ medium were seeded into each well. Evaluation of adherent cells was performed using crystal violet staining according to the method described by Aumeilley et al., and Tietze et al. [19,20]. After an incubation period of 30 min the supernatant with non-adherent cells was removed by two washes with warmed RPMI 1640. Attached cells were fixed with $30 \%$ (v/v) methanol/ethanol for $15 \mathrm{~min}$ at room temperature. Cells were stained with $0.1 \%(\mathrm{w} / \mathrm{v})$ crystal violet (Sigma, Hamburg, Germany), extensively washed with distilled water, and dried at room temperature. The dye was resuspended with $50 \mu \mathrm{l}$ of $0.2 \%(\mathrm{v} / \mathrm{v})$ Triton X-100/well and colour yields were then measured using an ELISA reader at $590 \mathrm{~nm}$ (Titertek Multiscan Plus MKII, Flow Laboratories GmbH, Meckenheim, Germany). Optical density (OD) showed a linear relationship to the amount of cells between $1 \times 10^{3}$ and 5 $\times 10^{4}$ cells per well, as determined by a dilution series.

Control dying of BSA/polystyrene without cells led to Optical Density (OD) values of 0.01-0.07. These values were subtracted from those obtained in the experiments.

\section{Phospholipids}

After complete preparation of the tumour cell suspension, the PL solution was added in the following concentrations: $0.05,0.1,0.5,0.75$, and $1 \mathrm{mg}$ per $100 \mu \mathrm{l}$ medium. The concentrations used were correlated to our in vivo experiments. The phospholipid solution consists of phosphatidylcholine $70 \%$ by weight, phosphatidylethanolamine $15 \%$ by weight, neutral lipids $8 \%$ by weight, sphingomyelin $<3 \%$ by weight and lysophosphatidylcholine $<3 \%$ by weight. 


\section{Statistical analysis}

All experiments were performed three times in quadruplicate. The data are expressed as means $+/$ - standard error of the mean (SEM). Student's t-test for unpaired data was used for statistical analysis. Differences were regarded as significant for $\mathrm{p}$ values $<0.05$.

\section{Results}

The analysis of tumour cell adhesion to BSA $1 \%$ resulted in a mean extinction of 0.27 (SEM 0.01) at $590 \mathrm{~nm}$. Coating with $\mathrm{ln}$ and $\mathrm{fn}$ led to a nearly twofold increase of tumour cell adhesion with mean values of $0.59(0.03, \ln )$ and $0.63(0.03, \mathrm{fn})$. The cancer cells showed a most pronounced adhesion to coll IV with a mean extinction of $0.97(0.02)$.

The tumour cell adhesion to ln registered after addition of PL was significantly reduced. The effect was concentration dependent compared to the controls. Even the minimum amount of PL $0.05 \mathrm{mg} / 100 \mu \mathrm{l}$ led to a reduced extinction of 0.4 (0.01). Treatment with 0.1 or $0.5 \mathrm{mg} / 100 \mu \mathrm{l} \mathrm{PL}$ revealed extinction values of $0.32(0.02)$ and $0.28(0.02)$, respectively. The maximum effect could be demonstrated with $0.75 \mathrm{mg} / 100 \mu \mathrm{l} \mathrm{PL}$ with an extinction of 0.24 (0.02). The relative reduction of tumour cell adhesion compared to the control amounts to $59 \%$. Treatment with $1 \mathrm{mg} / 100$ $\mu \mathrm{l}$ PL showed no further decrease of tumour cell adhesion to $\ln$. The mean extinction was $0.26(0.01)$ (table 1$)$.

The tumour cell adhesion on fn could not be reduced significantly with low concentrations of Pl. Addition of 0.05 $\mathrm{mg} / 100 \mu \mathrm{l} \mathrm{PL}$ and $0.1 \mathrm{mg} / 100 \mu \mathrm{l}$ resulted in a slight reduction of the extinction with mean values of 0.59 (0.02) and 0.59 (0.01). However, a significant reduction of tumour cell adhesion could be observed after treatment with 0.5 $\mathrm{mg} / 100 \mu \mathrm{l} \mathrm{PL}, 0.42$ (0.02); as well as with $0.75 \mathrm{mg} / 100 \mu \mathrm{l}$ PL (0.39 (0.02)) and $1 \mathrm{mg} / 100 \mu \mathrm{l} \mathrm{PL} \mathrm{(0.38} \mathrm{(0.02)).} \mathrm{We}$ found a similar situation compared to $\ln$ with equal effects of $0.75 \mathrm{mg} / 100 \mu \mathrm{l}$ and $1 \mathrm{mg} / 100 \mu \mathrm{l}$ PL indicating that the maximum influence on adhesion is reached. The relative reduction of tumour cell adhesion compared to the control values amounts to $40 \%$ (table 2).

NUGC-4 gastric cancer cells prominently adhere to collagen IV compared to all other examined extracellular matrix components. The influence of PL on cell adhesion to coll IV was also concentration dependent. The reduction ranged from an extinction of 0.89 (0.01) after administration of $0.05 \mathrm{mg} / 100 \mu \mathrm{l} \mathrm{PL}$ to a maximum effect after treatment with $1 \mathrm{mg} / 100 \mu \mathrm{l} \mathrm{PL}$ with a value of $0.44(0.02)$ (table 3 ). In comparison to the control value, this means a reduction of adherent tumour cells of 55\%.
Table I: Influence of different phospholipid concentrations on adhesion of gastric cancer cells to laminin. Optical density (OD) measured in an ELISA reader at $590 \mathrm{~nm}$

\begin{tabular}{lccc}
\hline & $\begin{array}{c}\text { Extinction at } \\
590 \mathrm{~nm}\end{array}$ & SEM & $\mathrm{P}$ \\
\hline Control & 0.59 & 0.03 & \\
PL $0.05 \mathrm{mg} /$ well & 0.4 & 0.01 & $\mathrm{P}<0.05$ \\
PL $0.1 \mathrm{mg} /$ well & 0.32 & 0.02 & $\mathrm{P}<0.05$ \\
PL $0.5 \mathrm{mg} /$ well & 0.28 & 0.02 & $\mathrm{P}<0.05$ \\
PL $0.75 \mathrm{mg} /$ well & 0.24 & 0.02 & $\mathrm{P}<0.05$ \\
PL I mg/well & 0.26 & 0.01 & $\mathrm{P}<0.05$ \\
\hline
\end{tabular}

Table 2: Influence of different phospholipid concentrations on adhesion of gastric cancer cells to fibronectin. Optical density (OD) measured in an ELISA reader at $590 \mathrm{~nm}$

\begin{tabular}{lccc}
\hline & $\begin{array}{c}\text { Extinction at } \\
590 \mathrm{~nm}\end{array}$ & SEM & $P$ \\
\hline Control & 0.63 & 0.03 & \\
PL $0.05 \mathrm{mg} /$ well & 0.59 & 0.02 & n. s. \\
PL $0.1 \mathrm{mg} /$ well & 0.59 & 0.01 & n. $\mathrm{s}$. \\
PL $0.5 \mathrm{mg} /$ well & 0.42 & 0.02 & $\mathrm{P}<0.05$ \\
PL $0.75 \mathrm{mg} /$ well & 0.39 & 0.02 & $\mathrm{P}<0.05$ \\
PL I mg/well & 0.38 & 0.02 & $\mathrm{P}<0.05$ \\
\hline
\end{tabular}

Table 3: Influence of different phospholipid concentrations on adhesion of gastric cancer cells to collagen IV. Optical density (OD) measured in an ELISA reader at $590 \mathrm{~nm}$

\begin{tabular}{lccc}
\hline & $\begin{array}{c}\text { Extinction at } \\
590 \mathrm{~nm}\end{array}$ & SEM & $\mathrm{P}$ \\
\hline Control & 0.97 & 0.02 & \\
PL $0.05 \mathrm{mg} /$ well & 0.9 & 0.01 & $\mathrm{P}<0.05$ \\
PL $0.1 \mathrm{mg} /$ well & 0.74 & 0.02 & $\mathrm{P}<0.05$ \\
PL $0.5 \mathrm{mg} /$ well & 0.61 & 0.02 & $\mathrm{P}<0.05$ \\
PL $0.75 \mathrm{mg} /$ well & 0.45 & 0.03 & $\mathrm{P}<0.05$ \\
PL I mg/well & 0.44 & 0.02 & $\mathrm{P}<0.05$ \\
\hline
\end{tabular}

\section{Discussion}

Cell adhesion to the extracellular matrix plays a fundamental role in peritoneal carcinosis. The adhesion is mediated by transmembrane Integrins. Several proteins including fibronectin in the interstitial matrix, laminin and collagen IV in the basement membrane were identified as important ligands [21,22]. Many attempts were made to inhibit tumour cell adhesion by integrin antibodies or competitive inhibitors against specific peptide sequences [23-26]. Gui et al. showed that adhesion of different breast cancer cells to extracellular matrix compo- 
nents could be reduced by specific integrin antibodies [27]. However, different antibodies for different cell lines were necessary according to the expression of specific integrins on the cell surface. Haier et al. could find different adhesive capacities to collagen I in two subtypes of the HT-29 colon carcinoma cell line. The cells with a very limited capability to induce hepatic metastases showed a significant higher rate of adhesions compared to those inheriting a high potential for involvement of the liver [28]. The influence of three examined phosphotyrosine kinase inhibitors on integrin mediated tumour cell adhesion to collagen I was unspecific. Dennis et al. found different cell-surface receptors responsible for cell attachment to fibronectin and collagen as compared to laminin. They concluded with the hypothesis that specific glycolipids may be receptors for interaction with fibronectin [29].

In our experiments the reduced rate of cell attachment in the presence of phospholipids was independent from the extracellular matrix. A similar effect on intraperitoneal tumour growth was described by Jacobi et al. who could demonstrate that taurolidine/heparin and povidone iodine lead to a significant reduction of tumour cell growth in vitro as well as a reduction of tumour weight after intraperitoneal tumour injection [30]. Predominantly the result seems to be a attributed to the cytotoxic effect of the used substances and benefits to a lesser degree from adhesion prevention. Other substances used to prevent adhesion failed in the treatment of inhibiting tumour cell attachment. Sodium hyalunorate increased the metastatic potential of colo-rectal tumour cells, probably mediated by the CD44 receptor [31]. Dextran sulphate resulted in reduced tumour cell nidation at sites of injury to abdominal wall in mice $[10,32]$. However, several side effects were described in the use of dextrane for adhesion prevention. Main problems were oedema, pleura effusion, life-threatening coagulation disorders and severe allergic reactions $[33,34]$. Phospholipids, polar phosphoric acid di-esters, are natural constituents of the abdominal cavity fluid and cell membranes.

The hypothesis is that phospholipids form a lubricant layer on the peritoneum by binding with its negatively charged cholin branch chain to the positively charged peritoneal surface $[12,14,35]$. Phospholipids cover the entire peritoneal membrane by a thin fluid layer. By separating tumour cells from the peritoneal surface they proved to significantly reduce peritoneal carcinosis. Phospholipipds seem to reduce the expression of integrins and adhesion molecules on the cell surface to the effect that adhesions can be prevented reducing tumour cell attachment independent from their origin $[15,16]$.
The in situ tumour cell - ECM interaction is influenced by adhesive and non-adhesive ECM components and can be understood as a three dimensional network [36]. Therefore the in vitro experiments with tumour cells as soluble agents added to ECM immobilized onto plastic surfaces cannot appropriately mimic the situation in situ. Recently we found that phospholipids significantly reduce the attachment area and the tumour volume of peritoneal carcinosis caused by the colonic cancer cell line DHD/K12/ $\mathrm{TRb}$ in rats. These results were supported by a prolonged survival rate of the treated animals as compared to the control group. Additionally, we found a similar effect of phospholipids on the adhesion of the human rectal cancer cell line HRT- 18 on the same ECM-components in vitro [37]. Consistent with results of other groups, the tumour cell attachment was found predominantly in areas of previously injured peritoneum $[5,6,38,39]$.

We performed this study to ascertain the results of the foregoing animal experiments and to demonstrate the influence of phospholipids to three different ECM components, even though matrices of collagen IV, laminin and fibronectin alone may not be predictive of peritoneal membrane nidation.

\section{Conclusion}

These results, within the scope of additional experimental studies on mice and rats which showed a significant reduction of peritoneal carcinosis, demonstrated the capacity of phospholipids in controlling abdominal nidation of tumor cells to ECM components. Lipid emulsions may be a beneficial adjunct in surgery of gastrointestinal malignancies.

\section{Competing interests}

The work was financially supported by Fresenius Kabi, Bad Homburg, Germany.

The results are part of an international patent application.

\section{References}

I. Koga S, Kaibara N, litsuka Y, Kudo H, Kimura A, Hiraoka H: Prognostic significance of intraperitoneal free cancer cells in gastric cancer patients. J Cancer Res Clin Oncol 1984, 108:236-238.

2. Schott A, Vogel I, Krueger U, Kalthoff H, Schreiber HW, Schmiegel $\mathrm{W}$, et al.: Isolated tumor cells are frequently detectable in the peritoneal cavity of gastric and colorectal cancer patients and serve as a new prognostic marker. Ann Surg 1998, 227:372-379.

3. Bando E, Yonemura Y, Takeshita Y, Taniguchi K, Yasui T, Yoshimitsu $Y$, et al.: Intraoperative lavage for cytological examination in I,297 patients with gastric carcinoma. Am J Surg 1999, I 78:256-262.

4. Broll R, Lembcke K, Stock C, Zingler M, Duchrow M, Schimmelpenning $\mathrm{H}$, et al.: Tumor cell dissemination in bone marrow and peritoneal cavity. An immunocytochemical study of patients with stomach or colorectal carcinoma. Langenbecks Arch Chir |996, 38 I:5 I-58.

5. Kiyasu Y, Kaneshima S, Koga S: Morphogenesis of peritoneal metastasis in human gastric cancer. Cancer Res 198I, 4 I: | 236-1239. 
6. Koga S, Kudo H, Kiyasu Y, Kaneshima S, litsuka Y, Takeuchi T, et al:: A scanning electron microscopic study on the peritoneal implantation of ascites hepatoma AHIOOB cells in rats. Gann 1980, $71: 8-13$.

7. Schwartz GK: Invasion and metastases in gastric cancer: in vitro and in vivo models with clinical correlations. Semin Oncol 1996, 23:316-324

8. Yashiro M, Chung YS, Nishimura S, Inoue T, Sowa M: Fibrosis in the peritoneum induced by scirrhous gastric cancer cells may act as "soil" for peritoneal dissemination. Cancer 1996, 77:1668-1675.

9. Nakashio T, Narita T, Akiyama S, Kasai $Y$, Kondo $K$, Ito $K$, et al:: Adhesion molecules and TGF-betal are involved in the peritoneal dissemination of NUGC-4 human gastric cancer cells. Int J Cancer 1997, 70:6/2-6/8.

10. Hagiwara A, Sawai K, Sakakura C, Shirasu M, Ohgaki M, Imanishi T, et al.: Prevention of peritoneal metastasis of cancer with dextran sulfate - an experimental study in mice. Anticancer Drugs 1997, 8:894-897.

II. Haverlag R, van Rossen ME, van den Tol MP, Bonthuis F, Marquet RL, Jeekel J: Hyaluronate-based coating solution for prevention of surgical adhesions has no major effect on adhesion and growth of intraperitoneal tumour cells. Eur J Surg 1999, 165:791-795.

12. Beavis J, Harwood JL, Coles GA, Williams JD: Synthesis of phospholipids by human peritoneal mesothelial cells. Perit Dial Int 1994, 14:348-355.

13. Hakomori S: Structure, organization, and function of glycosphingolipids in membrane. Curr Opin Hematol 2003, 10:16-24.

14. Chailley-Heu B, Rubio S, Rougier JP, Ducroc R, Barlier-Mur AM, Ronco $P$, et al.: Expression of hydrophilic surfactant proteins by mesentery cells in rat and man. Biochem J 1997, 328(Pt I):25I-256.

15. Muller SA, Treutner KH, Tietze L, Anurov M, Titkova S, Polivoda M, et al: Influence of intraperitoneal phospholipid dosage on adhesion formation and wound healing at different intervals after surgery. Langenbecks Arch Surg 200I, 386:278-284.

16. Muller SA, Treutner KH, Tietze L, Anurov M, Titkova S, Polivoda M, et al:: Efficacy of adhesion prevention and impact on wound healing of intraperitoneal phospholipids. J Surg Res 200I, 96:68-74.

17. Yung S, Davies M: Response of the human peritoneal mesothelial cell to injury: an in vitro model of peritoneal wound healing. Kidney Int 1998, 54:2160-2169.

18. Gailit ], Clark RA: Wound repair in the context of extracellular matrix. Curr Opin Cell Biol 1994, 6:717-725.

19. Aumailley M, Mann K, von der MH, Timpl R: Cell attachment properties of collagen type $\mathrm{VI}$ and Arg-Gly-Asp dependent binding to its alpha 2(VI) and alpha 3(VI) chains. Exp Cell Res | 989, | 81:463-474.

20. Tietze L, Borntraeger J, Klosterhalfen B, Amo-Takyi B, Handt S, Gunther $K$, et al: Expression and function of beta(I) and beta(3) integrins of human mesothelial cells in vitro. $\operatorname{Exp~Mol}$ Pathol 1999, 66:131-139.

21. Akiyama SK, Nagata K, Yamada KM: Cell surface receptors for extracellular matrix components. Biochim Biophys Acta 1990, 1031:91-110.

22. Hynes RO: Integrins: versatility, modulation, and signaling in cell adhesion. Cell 1992, 69: II-25.

23. Mould AP, Askari JA, Aota S, Yamada KM, Irie A, Takada Y, et al.: Defining the topology of integrin alpha5betal-fibronectin interactions using inhibitory anti-alpha5 and anti-beta I monoclonal antibodies. Evidence that the synergy sequence of fibronectin is recognized by the amino-terminal repeats of the alpha5 subunit. J Biol Chem 1997, 272: I 7283-17292.

24. Mould AP, Askari JA, Akiyama SK, Yamada KM, Humphries MJ: An assessment of the efficacy of anti-integrin alpha subunit monoclonal antibody production using affinity purified beta I-integrin dimers as immunogen. Biochem Soc Trans |99|, 19:36IS.

25. Yamada KM, Kennedy DW, Yamada SS, Gralnick H, Chen WT, Akiyama SK: Monoclonal antibody and synthetic peptide inhibitors of human tumor cell migration. Cancer Res 1990, 50:4485-4496.
26. Gehlsen KR, Argraves WS, Pierschbacher MD, Ruoslahti E: Inhibition of in vitro tumor cell invasion by Arg-Gly-Asp-containing synthetic peptides. J Cell Biol 1988, 106:925-930.

27. Gui GP, Puddefoot JR, Vinson GP, Wells CA, Carpenter R: In vitro regulation of human breast cancer cell adhesion and invasion via integrin receptors to the extracellular matrix. $\mathrm{Br} J$ Surg 1995, 82: II92-II96.

28. Haier J, Nasralla M, Nicolson GL: Influence of phosphotyrosine kinase inhibitors on adhesive properties of highly and poorly metastatic HT-29 colon carcinoma cells to collagen. Int J Colorectal Dis 1999, 14:119-127.

29. Dennis J, Waller C, Timpl R, Schirrmacher V: Surface sialic acid reduces attachment of metastatic tumour cells to collagen type IV and fibronectin. Nature 1982, 300:274-276.

30. Jacobi CA, Peter FJ, Wenger FA, Ordemann J, Muller JM: New therapeutic strategies to avoid intra- and extraperitoneal metastases during laparoscopy: results of a tumor model in the rat. Dig Surg 1999, 16:393-399.

3I. Tan B, Wang JH, Wu QD, Kirwan WO, Redmond HP: Sodium hyaluronate enhances colorectal tumour cell metastatic potential in vitro and in vivo. Br J Surg 200I, 88:246-250.

32. Hagiwara A, Sakakura C, Yamasaki J, Togawa T, Sonoyama Y, Fujiyama J, et al.: Dextran sulfate inhibits injured abdominal wall-specific tumor implantation in mice. Anticancer Drugs 2000, I I:873-877.

33. diZerega GS: Use of adhesion prevention barriers in ovarian surgery, tubalplasty, ectopic pregnancy, endometriosis, adhesiolysis, and myomectomy. Curr Opin Obstet Gynecol 1996, 8:230-237.

34. Treutner $\mathrm{KH}$, Schumpelick V: Prevention of adhesions. Wish and reality. Chirurg 2000, $71: 510-517$

35. Hills BA: Graphite-like lubrication of mesothelium by oligolamellar pleural surfactant. J Appl Physiol 1992, 73:1034-1039.

36. Orend G, Chiquet-Ehrismann R: Adhesion modulation by antiadhesive molecules of the extracellular matrix. Exp Cell Res 2000, 26I: 104-II0.

37. Jansen M, Treutner KH, Lynen JP, Otto J, Schmitz B, Mueller S, et al: Phospholipids reduce the intraperitoneal adhesion of colonic tumor cells in rats and adhesion on extracellular matrix in vitro. Int J Colorectal Dis 2004, 19:525-532.

38. van den Tol MP, Haverlag R, van Rossen ME, Bonthuis F, Marquet RL, Jeekel J: Glove powder promotes adhesion formation and facilitates tumour cell adhesion and growth. Br J Surg 200I, 88: $1258-1263$.

39. van den Tol PM, van Rossen EE, van Eijck $\mathrm{CH}$, Bonthuis F, Marquet $\mathrm{RL}$, Jeekel $\mathrm{H}$ : Reduction of peritoneal trauma by using nonsurgical gauze leads to less implantation metastasis of spilled tumor cells. Ann Surg 1998, 227:242-248.

\section{Pre-publication history}

The pre-publication history for this paper can be accessed here:

\section{http://www.biomedcentral.com/1471-230X/4/33/pre} pub

Publish with Biomed Central and every scientist can read your work free of charge

"BioMed Central will be the most significant development for disseminating the results of biomedical research in our lifetime. "

Sir Paul Nurse, Cancer Research UK

Your research papers will be:

- available free of charge to the entire biomedical community

- peer reviewed and published immediately upon acceptance

- cited in PubMed and archived on PubMed Central

- yours - you keep the copyright 